MIKKO TURUNEN

\title{
”Alma” ja lempeän kuoleman aihelma Kiven lyriikassa
}

Aiempi Kivi-tutkimus ei ole ollut kovin kiinnostunut Aleksis Kiven Kirjallisessa Kuukauslehdessä vuonna 1866 julkaistusta runosta "Alma" (Kivi 2000: 55-57), vaikka siinä esiintyvät asetelmat ja yksittäiset ainekset toistuvat kirjailijan lyriikassa. Runo on mainittu lähinnä esimerkinomaisesti temaattisten yhtäläisyyksien ilmentäjänä. Esimerkiksi Kiven tuotannon aiheryhmiä jäsennellyt Lauri Viljanen (1964: 513) näkee "Alman" variaationa Eriika-teemasta, sillä runokuvitelma nuorena kuolevasta naisesta palautuu varhaiseen kertomukseen "Eriika" (1859) samoin kuin vastaavat kohtalot runoissa "Pilvilaiva", "Oli mulla kulta kaunoinen" ja "Eksynyt impi". Näissä uskonnolliseen hurmokseen yhdistyy nuorena kuoleminen (ks.Viljanen 1964:48I-482), mikä ilmenee myös "Alman" nimihenkilössä. Viljasen jaotteluja kritisoiva Torsten Pettersson (2016: I5, 21 ja 25) kytkee "Alman" kuolemaan päättyvien runojen lisäksi myös Kiven runojen sosiaaliseen kenttään sekä murheen ja onnen kaksijakoisuuteen. Hannes Sihvo (2002: 285) puolestaan näkee runon versiona kantelettarelaiseen lyriikkaan kuuluvasta immen kuolo -aiheesta. Edellä olevat ryhmittelyt ovat perusteltuja, mutta ne esittävät "Alma"-runon pikemminkin rinnakkaistapauksena kuin itsestään huomionarvoisena runona: yleensä tarkastelun ydin on jossakin muussa tutkimuskysymyksessä, jota "Alman" sisällöt risteävät tai sivuavat.

Tässä kirjoituksessa tarkastelen Kiven "Alma"-runon rakentumista ja merkityksenmuodostusta. Pyrin yksittäisrunon analyysin lisäksi nostamaan näkyviin kytköksiä Kiven runouden toistuviin aineksiin esimerkiksi yksittäisten aihelmien, asetelmallisten sommitteluiden ja aiheiden sävytyksen kautta. "Alma"-runo on noteerattu lähinnä Kiven kuolemateeman variaationa. Esitykseni otsikossa oleva ilmaus "lempeä kuolema" pohjautuu havaintoon, että samoin kuin tuonpuoleinen esiintyy Kiven lyriikassa myönteisenä ja harmonisena, myös kuolintapahtuma ja siihen liittyvät seikat sävyttyvät lopulta lempeiksi - jopa niin rajuissa tapauksissa kuin "Äiti ja lapsi" -runon paleltumiskuolemassa (analyysista ks. Oja 2016) tai "Ensimmäinen lempi"-runon itsemurhassa (Kiven itsemurhateemasta ks. Kukkonen 20I5). "Alma"-runossa toteutuu myös suomalaisen kuolemankulttuurin käsitys hyvästä kuolemasta, jota käsittelen tuonnempana suhteessa I800-luvun kuolemakulttuurin tutkimukseen - tästä syntyy artikkelin keskeisin uutta tietoa tuottava sisältö.

\section{Juoni, rakenne ja kytkökset}

Kertova runo "Alma" piirtää nimihenkilön elinkaaren lapsuudesta hautajaispäivään, josta runo laajenee yleisemmäksi eskatologiseksi pohdinnaksi. Alman elämän ulkoiset lähtökohdat ovat hyvät: korea kartano viestii elintasosta, kaunis ulkomuoto vihjaa mahdollisuuksista parinmuodostuksessa ja isän rakkaus tuo turvaa ja tukea. Kuitenkin äidin 
kuolema jättää Alman osattomaksi onnellisesta äitisuhteesta ja hellyydestä - kasvattajaemo kuvataan vieraana ja ankarana. Alma valitsee elämäntehtäväkseen lähimmäisenrakkauden ja toisten auttamisen mutta sulkee itsensä ulos maallisesta rakkaudesta. Hän ei myöskään tavoita pyrkimyksistään huolimatta täyttymystä tämänpuoleisessa vaan riutuu ennenaikaiseen kuolemaan. Hautajaisten saattoväen suru sävyttyy runon lopussa toivon täyttämäksi ylösnousemususkoksi.

Runossa on kaikkiaan 14 nelisäkeistä säkeistöä, joissa vuorottelevat kymmentavuinen säe ja lyhyempi seitsentavuinen säe. Heikki Laitinen (2016: 70) on kuvannut tarkemmin "Alman" säe- ja säkeistörakenteen Kanervakankaalla-teoksen artikkelissaan. Runo voidaan jakaa sisällöllisiin jaksoihin sen mukaan, millainen funktio niillä on kokonaisuuden rakentumisessa. Säkeet I-4 luonnehtivat Alman lähtökohtia ja olemusta sekä motivoivat hänen toimintaansa. Säkeistöjen 5-8 muodostama jakso jäsentyy siten, että sen ytimessä on Alman taivaskaipuun sävyttämä mietiskely (säkeistöt 6 ja 7), jota kehystävät kuvaukset Alman lähimmäisenrakkaudesta (säkeistöt 5 ja 8). Tämä jakso esittelee sisäisen maailman ristiriitoja ja pohjustaa Alman kuolemaa: tuonpuoleisuuden odotus suuntaa elämän ennenaikaiseen päättymiseen samaan tapaan kuin Kiven runossa "Eksynyt impi” (analyysista ks. Grünthal 2018 sekä Karhu tässä teoksessa). Alman kuolemaan ja hautajaisiin keskittyvät säkeistöt 9-II päättävät runossa kuvatun yksittäisen elämänkaaren ja avaavat pohjan yleisemmille murheen ja toivon pohdinnoille, joille viimeisen kolmen säkeistön jakso tuo nousujohteisen käsittelyn.

Asetelmallinen sommittelu näkyy kahtena runon läpäisevänä menetelmänä: toisteisuutena ja vastakohta-asemointina.Valtaosa säkeistöistä (2., 4.-7., 9. ja 13.-14.) on sisäisesti toisteisia siten, että nelisäkeisen säkeistön ensimmäinen ja jälkimmäinen säepari ilmaisevat saman sisällön. Näin syntynyt kertaava toisto mahdollistaa kulloiseenkin aiheeseen kaksi tulokulmaa (esim. 2. ja 14. säkeistö) tai sävytyksen tapaa (esim. 4. ja 9. säkeistö). Lisäksi kaksi säkeistöä muodostaa toistoparin: kuudes ja seitsemäs säkeistö ovat samansisältöisiä, mutta ensimmäinen on toteava ja jälkimmäisen esitystapa on kysyvä. Näin asia ensin todetaan ja sitten huomio kohdennetaan haaveilun sisältöihin. Runon puhuja ei kuitenkaan avaa Alman ajatuksia vaan ainoastaan kuvaa ulkoisesti havaittavan uneksinnan ja riutumisen.

Ne säkeistöt (I., 3., 8. ja I0.-I2.), joissa toisteisuutta ei ole, sisältävät yleensä vastakohtaparin: ensimmäinen säkeistö kuvaa Alman ulkoisesti hyviä lähtökohtia elämään mutta myös äidin menetystä. Kolmas säkeistö kertoo Alman tunteiden vastakkaisuudesta, nimittäin katseen ulossuuntautuvasta lempeydestä ja huulten sisäisestä murheesta. Kahdeksas säkeistö puolestaan esittelee Alman kieltämän maallisen rakkauden mutta samanaikaisesti hänestä muille suuntautuvan lähimmäisenrakkauden. Vastakkainasettelujen kautta luodut jännitteet ovat Kiven runoille laajemminkin ominainen piirre, joka pohjautuu romantiikalle tyypilliseen vastakohtien estetiikkaan (Grünthal 1999: 322).

Runon asetelmissa voi nähdä muistumia herätyskirjallisuuden hurskaiden ihmisten elämäkerroista ja muistorunojen kertovista elämäntarinoista. Näissä järkähtämättä kristillisiä arvoja noudattanut 
henkilö usein menehtyy ennenaikaisesti ja glorifioituu esimerkillisenä. Muistorunot jäsentävät elämänvaiheet ehyeksi ja harmoniseksi elinkaareksi. Esimerkiksi tunnettu Kaarina Maununtyttären muistoruno koostuu elämänvaiheiden ja hyveiden (esim. armeliaisuus vähäosaisia kohtaan) idealisoinnista, kuoleman vääjäämättömyydestä ja jälkeenjääneiden lohdutuksesta uskonnollisen lupauksen kautta (Pitkäranta 1999: III). Samoja aineksia on läsnä "Alma"-runossa. Alman riutuva katse taivaaseen ja saattoväen uskonnollisesti sävyttyvä suru taas viittaavat herännäisyyden mukana tulleisiin tarinoihin voimakkaista uskonkokemuksista ja uskonnollisista näyistä. Herännäisyyden ydintä on juuri henkinen ikävä ja kaipaus (Grünthal 2018: 184). Kivi kuvaa joissakin runoissaan, kuten "Rippilapset", "Eksynyt impi ja "Immen unelma", vastaavia uskonnollissävyisiä näkyjä. Tosin Kiven monille runoille on tyypillistä, että hengellisiltä vaikuttavat käsitteet jäävät vaille suoria viittauksia uskonnollisiin kehyksiin (ks. esim. Haapala 2016: 127; Kainulainen 2016: 297). Muiden runojen tapauksissa esimerkiksi raamatullinen sanasto tai konventionaaliset taivasnäyt vahvistavat tulkintakehystä, mutta "Almassa" asetelma on viitteenomaisempi. Alman sisäänpäin kääntynyt murhe ja taivaaseen katselut liittyvät samaan ilmiöön, joka on tunnistettu hurmoksellisen kansanherätyksen kokeneiden naisten käytöksessä näiden pyrkiessä hartailla mietteillä ja kilvoittelulla armon tilaan. Irma Sulkunen (2016: 108-109 ja 124) on tarkastellut ilmiötä - mutta ei Kiven runoja - artikkelissaan "Paimentytön liikutus. Hurmosherätykset, sekularisaatio ja maailmankuvan muutos".

\section{Idealisoitu hahmo}

Alman idealisoitu hahmo viittaa erityisesti Kiven lyriikan toistuviin naiskuviin, joiden ihanteellisuus on saanut huomiota aiemmissa tutkimuksissa. Alman tyyppinen "nuori nainen, joka neitseellisessä puhtaudessaan ja jalossa, elävän uskon innoittamassa inhimillisyydessään vaikuttaa puhdistavasti ja kohottavasti ympäristöönsä”, on runoudessa yleinen hahmo ja esiintyy usein Kiven tuotannossa (Alanen 1947: 69; ks. Grünthal 2018: 185). Alman henkilökuvaa rakennetaan sekä suoraan kuvaamalla että vertausten kautta, kuten runon kolmannesta ja neljännestä säkeistöstä on havaittavissa.

\footnotetext{
Toki leppeyttä ja lempee täynnä loisti Alman katsanto, mutta hymy synkee, murheellinen väikkyi hänen huulillans.

Tyyni oli hän kuin pohjan valo vuorten kiireil kesä-yös, lempeä kuin lehdikkäinen saari, kosk on myrsky vaijennut.
}

Alman tunnemaailma esitetään kaksijakoisena, ja se konkretisoidaan paikantamalla kasvon osiin: nimittäin lempeän katseen ja murheellisen hymyn samanaikaiseen surumielisyyteen. Paikannustapa ei ole Kiven lyriikassa harvinainen: ihmisen otsa, katse ja huulet ilmaisevat tunnetiloja, ja 
ilmeikkyyden kuvaamisen sijaan nimetään kasvonpiirteistä tulkittava tunne. Ristikkäisten tunteiden sävyttämä mielenhaikeus kuuluu romantiikan esteettisiin tunteisiin (aesthetic emotions), joille ovat tyypillisiä tunnekirjon myönteiset ja kielteiset aspektit erivahvuisina kombinaatioina (Brady \& Haapala 2003).

Alman idealisoitua luonnetta kuvataan yksinomaan tyyneksi ja lempeäksi, mikä ilmenee myös pyyteettömänä toisten auttamisena. Neljännen säkeistön vertaukset rinnastavat varsin konventionaalisesti toisiinsa luonnossa tulkittavan ja luonteessa ilmenevän lempeyden. Lisäksi vertauksiin valikoituneet vuorinäkymät ja tuuhea lehto toistuvat sekä Kiven lyriikassa että romantiikan luontokuvastossa. E. A Saarimaa (195I: 54) käyttääkin "Alma"-runon neljättä säkeistöä esimerkkinä Kiven tavasta sommitella laajoja perättäisiä kuvia romantiikan tyyliin.

Viides säkeistö erittelee näkyviin lähimmäisenrakkauden ulottuvuuksia.

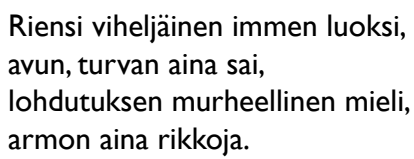

Altruismi suuntautuu moniaalle:Alma tarjoaa surkeassa asemassa oleville ("viheljäinen") avun ja turvan sekä murheellisille lohdutuksen. Säkeistössä sana "rikkoja" viittaa jotakin tuomittavaa tehneeseen, mutta hänkin saa Almalta armon ja anteeksiannon. Näin aineellisesti tai moraalisesti heikoilla olevat pääsevät saman lohdun piiriin kuin suruihinsa juuttuneet. Jalomielisen toiminnan motiiveiksi tarjoutuvat runossa sekä Alman luonteenpiirteet että kristillinen lähimmäisenrakkauden eetos. Vaikka Alman empaattisuuden kristillistä lähtökohtaa ei eksplikoida, sen voi olettaa sellaisista sävyttyneistä ilmauksista kuin armo, lohdutus ja turva. Lauri Viljanen (1954: 68) johtaakin Alman luonteen evankelisiin kasvatusherätteisiin, joiden tavoitteet konkretisoituvat Alman toiminnassa. Lisäksi kahdeksannen säkeistön lopussa Alman sydämestä virtaavan rakkauden kuvataan säteilevän taivaallisesti, ja kyseessä on nimenomaan ihmisrakkaus, ei rakkaus kehenkään yksittäiseen ihmiseen - Almahan ei säkeistön mukaan päästä ketään "sydämensä kammioon". Ilmauksen "taivaallisesti” voi tulkita ilmentävän hengellisen rakkauden ensisijaisuutta, koska maalliselle rakkaudelle Alma ei anna sijaa. Varsinaista rakkauden toista osapuolta ei tarvita lainkaan, koska nuorena nukkunut altruistinen hahmo on sellaisenaan rakkauden ilmentymä (Sihvo 2002: 285).

Aleksis Kiven runo "Mies" (analyysista ks. Kainulainen 2016) käsittelee samankaltaista teemaa. Siinä rakkaudessa pettynyt päähenkilö jalostaa pettymyksensä epäitsekkääksi muiden auttamiseksi ja yleisinhimilliseksi lähimmäisenrakkaudeksi (Koskenniemi 1934: 21 I-2 I2; Koskimies 1974: 122-123). "Mies"-runon toimintamotiivi ja eetos ilmenevät "Alma"-runossa siten, että puuttuvan äidinrakkauden kompensointi muovaa Alman avuliaaksi lohduttajaksi. Alma itse ei tunnu löytävän paikkaansa tämänpuoleisessa vaan katselee "riutuen sineyteen korkuuden", minkä voi taivaskaipuun ohella ajatella ilmentävän tuonpuoleisuuteen tai ylipäätään tavoittamattomaan suuntautumista. Koska Alman ajatukset jäävät täsmentämättä ja nimeämättä ("Mitä mietiskelee kelmee neito"), jää 
avoimeksi, onko kyseessä subliimin kohtaaminen, eksistentiaalinen tuska vai uskonnollis-kosminen melankolia, jossa Alma asettelee itseään ihmisen osaan ja elämän tarkoituksen arvoituksiin.

Lisäksi kyseessä on yleisromanttinen asetelma: Kiven kaipauksen ja riutumisten kuvauksia sekä romanttista "ikävän" poetiikkaa ovat aiemmat tutkijat kytkeneet romantiikan yleissävyihin (esim. Lyytikäinen 2007: 8485; Saarimaa 1951: 49). Romantiikan hahmoille ovat ominaisia tuskallinen tietoisuus todellisuuden ja haaveiden välisestä ylittämättömästä kuilusta sekä realisaation hetket, jolloin tunnistetaan haaveiden mahdottomuus. Näin runossa aukkokohdaksi jätettyä riutumisen syytä voi tarkastella sekä runonsisäisenä henkilökuvan tulkintana että laajempana romantiikan topoksen ilmenemisenä.

\section{Hyvän kuoleman manifesti}

Runon yhdeksännessä säkeistössä kuvattu Alman kuolema käynnistää lähes puolet runosta kattavan hautajaisrituaaleihin ja saattoväen suruun keskittyvän jakson. Säkeistömäärällä mitattuna - kuusi säkeistöä neljästätoista - Alman kuolema ja siihen kytkeytyvät teemat saavat sekä tilaa että huomiota. Kivellä toistuva nuoren naisen kuolema jää syyltään epämääräiseksi tai tunneliikutuksen laukaisemaksi (vrt. Viljanen 1954: 68). Kiven tekstien kuolemahakuisuutta ja kuolemakaipuuta eritellyt Tiina Kukkonen (20I5: 82) näkee Alman ajatuksissa ehkä tiedostamatontakin itsetuhoisuutta, josta seuraa kuolema ilman neidon aktiivista toimintaa. Kyseessä on samanlainen riutumiseen menehtyminen, joka saa erilaisia ilmentymiä romantiikan ylivoimakkaita tunteita etualaistavassa henkilökuvauksessa. Tässä mielessä kyseessä on pikemminkin kirjallinen henkilötyyppi: Alma on uneksija, jonka armelias kuolema ottaa nuorena pois (Sihvo 2002: 287). Alman menehtymisen syytä ei eksplikoida, mutta taustalle on oletettu asetelma, jossa tuonpuoleisessa onnelassa on parempi olla kuin tämänpuoleisessa elämässä (Pettersson 2016: 21). Joka tapauksessa suljettu elämänkaari jännitteineen on runon juonellisena rakenteena. Itse kuolinkuvaus rakentuu konventionaalisten ilmausten kautta.

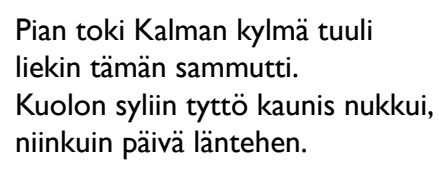

Alman kuolema esitetään odotettuna ja luontevana, mikä johtuu selittävän toki-sanan käytöstä: "Pian toki Kalman kylmä tuuli / liekin tämän sammutti." Ilmaus on kaksihahmotteinen, sillä sen voi ymmärtää edellisten säkeistöjen riutumisen seurausta selittävänä sisältökytköksenä tai toisaalta kertoilevaa ja puheenomaista tyyliä vahvistavana sanavalintana, jollaisia Kiven kielessä on runsaasti muuallakin. Nykysuomen sanakirja (Osa V, 1992: 73I) nostaa toki-sanan käytöstä omaksi erityistapaukseksi Aleksis Kiven tuotannon konjunktion tavoin käytetyn ilmauksen. Annetuista esimerkkisitaateista toinen kytkeytyy sattumalta myös kuoleman kuvaukseen: kyseessä on Rachelin repliikki Canziosta ("Toki tuskinpa oli hän mieheksi tullut ennenkuin Tuoni hänet temmasi pois."). 
Ennakoivan vihjeen voi tulkita erisnimien Alma ja Kalma äänneyhtäläisyydessä sekä molempiin liittyvästä kuolemakytköksestä. Molemmat sanat esiintyvät kertaalleen ensimmäisessä säkeistössä ja vielä toisen kerran erillisissä yhteyksissä (Alma kolmannessa ja Kalma yhdeksännessä säkeistössä). Alman henkilöön kuolema liittyy elämää jäsentävänä kaipuuna ja ennenaikaisena menehtymisenä, kun taas isolla alkukirjaimella personoitu Kalma viittaa henkilöityyn kuolemaan.

Alman kuolintapahtuman kuvaus koostuu intensiivisestä menehtymisen toistamisesta, joka toteutuu kasautumana konventionaalisia metaforia:yhdeksännessä säkeistössä on läsnä tuulen sammuttaman kynttilän kuvasto, poisnukkumisen metafora, vertaus laskevasta päivästä sekä personoitu kuolon syli ja Kalma, joka esiintyy myös koko runon ensimmäisen säkeistön lopussa. Seuraavassa säkeistössä esiintyy vielä tuonen tupa. Runon ilmaisullinen valinta on kuolinkuvauksen etäännyttäminen totunnaisten käsitteistysten kautta, jotka sekä pehmentävät kuoleman armottomuutta että estetisoivat kuolintapahtuman.

"Alma"-runossa kuolemaan suuntautuminen motivoidaan sisäisen levottomuuden ja riutumisen kautta, ja kuolinkuvauksessa siirrytään oletettuun levollisuuteen tai yksilön elämää laajempaan kehykseen. Elämässä vastakohtaisina näyttäytyvien rakkauden ja murheen samanaikaisuus ja kuolinhetkellä täydellistyvä onni vaikuttavat normatiiviselta ihanteelta Kiven teksteissä (Kukkonen 20I5: 88). "Alma"-runossa tämä lähimmäisen rakkauden ja oman surumielen asetelma on nähtävissä, joskin Alman "täydellistyvä onni" on oletettavasti taivaspaikan lunastuksessa. Ylipäätään riutumuksen ja murheen kaltaiset tunteet altistavat Kiven teksteissä kuolemalle, ja ne voimistuvat altruistisuuteen pukeutuvan uhrautumisen ja surumielisen onni-ihanteen vuoksi (Kukkonen 2015: 102).

Kuvaustavasta ja runon asetelmasta on nähtävissä, että Alman menehtymiseen liittyy samoja piirteitä, joita 1800-luvun suomalaisessa kuolemakulttuurissa liitettiin ihanteelliseen tai hyvään kuolemaan (ks. Koski ja Moilanen 2019: 69). Ensinnäkin hyvään kuolemaan kuuluva ajatus levollisesta poismenosta assosioituu kuolinkuvauksen harmonisilla ja etäännyttävillä eufemismeilla. Hyvään kuolemaan kuuluivat kuolinhetkeä edeltävät päättyvän elämän merkityksellisyyttä korostavat tunnusmerkit (Alman auttamishalu, anteeksianto). Hautajaiset ovat myös vainajan arvon manifestaatiota, joka tekee edesmenneen arvostuksen näkyväksi (Ilmakunnas 2019: 139). Oikeanlainen hautajaisprosessi asiaankuuluvine surun julkituomisineen oli myös osa hyvää kuolemaa (Miettinen 2019: 187). Alman laaja sosiaalinen jälkimuisto, ystävien ja yhteisön vuolas suru sekä vainajan ja arkun koristelun yksityiskohdat viittaavat toisaalta hänen merkitykseensä kaivattuna yksilönä mutta toisaalta myös sosiaaliseen taustaan.

Runon alussa kuvattu korea kartano ja mahdollisuus omistautua hyvän tekemiselle voisivat viitata säätyläisyyteen, mutta olennaisempi selitys on Torsten Petterssonin (2016: 15) havainto nimeämisen merkityksestä.Yleensä nimettömäksi jäävien Kiven hahmojen joukossa "Almassa" näkyvään nimeämiseen liittyy kuvaus sosiaalisesta kentästä, jossa Alma toimii hyväntekijänä ja jossa häntä siksi muistetaan. Kuitenkin runossa kuvataan "omissa oloissaan liikkuvaa Almaa, jonka kaipuu tuonpuolei- 
seen ylittää sosiaalisten suhteiden merkityksen" (Pettersson 2016: 15). Tässä ilmenee jälleen vastakkainasemoinnin periaate, jossa sommittelu on nyt sosiaalisessa orientaatiossa. Lisäksi Alman yhteisöllinen erityisyys on poikkeuksellista. Naimattomana ja lapsettomana kuoleva nuori nainen ei ollut viiteajankohdan kuolinhierarkiassa korkealla, koska hänen menehtymisensä seuraukset olivat rajalliset (ks. Ilmakunnas 2019: 134). Kuitenkin Alma arvotetaan kollektiivisen surun perusteella merkittäväksi. Hänen kuolemansa on hyvä myös siksi, että se tuottaa yhteisöllistä hyvää; lohdullisen sosiaalisen tunnekanavoinnin tai tulkitun todisteen, joka tukee yhteisön jakamaa varmuutta ylösnousemuksesta, kuten runon loppusäkeistö vihjaa.

\section{Yksilön kuolemasta kollektiiviseen toivoon}

"Alma"-runon yhdeksäs säkeistö on runon taitekohta, jonka jälkeen fokus irtaantuu nyt kuolleesta Almasta ja runon puhuja siirtyy metaforisesti esitetystä kuolemasta kuvaamaan konkreettisten hautajaisrituaalinen suorittamista ja saattoväen surua (Eriika-kertomuksen ja "Alman" hautajaisrituaalien vastaavuuksista ks. Sihvo 2002: 285). Runon maailmassa Alma on fyysisesti poissa ja esiintyy siksi saattoväen mielessä poissaolevana ystävänä, "kadonneena haamuna" ja kaipauksen kohteena. Vaikka ruumiin kuolema on tapahtunut, sosiaalinen kuolema ei toteudu (kuoleman moduksista ks. Demitshev 1999: 147), sillä hänen kuvataan olevan vahvasti ja emotionaalisesti läsnä surijoiden mielessä. Alman kuoleman kautta yhteisön on myös mahdollista saavuttaa laajempaa eksistentiaalista ymmärrystä ja lohdutusta, mikä on sururituaalien keskeinen funktio.

Kuollutta keskushenkilöä muistellaan myös esimerkiksi Kiven runoissa "Tornin kello" (analyysista ks. Kirkkopelto 200 I) ja "Oli mulla kulta kaunoinen". Kymmenennessä säkeistössä esiintyviä hautajaisrituaaleja ja ruumiin valmistelua kuvataan myös runoissa "Uneksuminen", "Eksynyt impi" ja "lkävyys" (analyysista ks. Nummi 2005), joista "Eksyneen immen" tapauksessa tosin kuolinrituaalit ja häärituaalit sekoittuvat, kun immen valmistautuminen häihin on yksiselitteisesti kuolemaan valmistautumista. "Ikävyys"-runossa taas kuolemaan suuntautuva runon puhuja ohjeistaa omia hautajaisjärjestelyjään.

Yhdennessätoista säkeistössä hautajaispäivän harras tunnelma saa kehyksekseen idyllisten luontodetaljien sarjan.

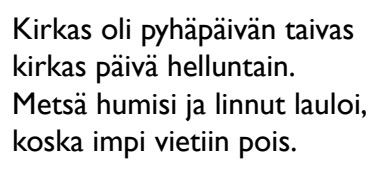

Kuolinpäivän kaunis sää rinnastuu kauniin ja lempeän Alman olemukseen, jota jo aiemmin (5. säkeistö) verrattiin idyllisinä koettuihin luontonäkymiin. Kuvauksessa on mahdollista nähdä myös hengellistä vivahdetta. Siihen ohjaa hautajaisten osuminen kristilliseen helluntaihin, ja toisaalta taivaan ja päivän kirkkaus assosioituu kirkkauteen astumisen vertauskuviin. Aarne Kinnunen puhuu esseessään "Kuolemanvarjon maassa" Aleksis Kiven kuolemankatsomuksesta. Hän näkee Kiven runojen 
kuoleman merkitsevän kristillistä kirkastumista, toivoa ja uskoa ihmisen puhdistumiseen (Kinnunen 2002: 18). "Alma"-runossakin tällainen tulkinta on mahdollinen, etenkin kun viimeisessä säkeistössä runon puhuja siirtyy hetkellisen menetyksen ja surun kuvaamisesta yleisempään käsitykseen ihmisen toiveikkaasta matkasta kohti "taivaan sointoa".

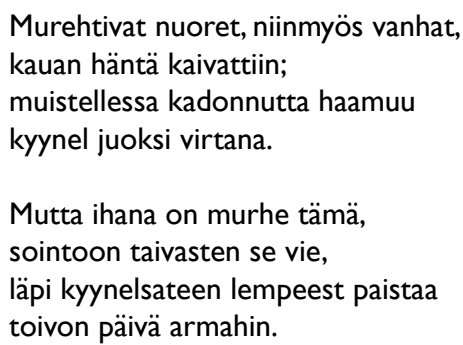

Kuolema näyttäytyy lempeänä, koska se ei hengellisessä ajattelussa ole sielulle lopullinen, ainoastaan etappi ennen ylösnousemusta. Tässä uskomuskehikossa Alman kuolema ei ole traaginen. Jäljelle jääneiden ystävien kyyneleet ovatkin vain osin surun raskauttamia, sillä läsnä on uskonvarma tietoisuus tuonpuoleisen autuudesta: epätoivon ja surun läpi suodattuu optimismi, joka ylevöittää saattoväen surun. Viimeisen säkeistön nosto yksilöiden murheesta eksistentiaaliseen toivoon on asetelmaltaan hyvin erilainen kuin vaikkapa "Tornin kellon" lohduttomuus inhimillisen rajallisuuden äärellä ("Mihin vertaan ihmis-onnen?"). Runon lopussa on läsnä Kiven romantiikasta omaksuma sekoittunut ambivalentti sävy (Grünthal 1999: 322-323), jonka mukaisesti murhe näyttäytyy ihanana. Tällainen romantiikalle ominainen katkeransuloinen melankolia tai suloisensurullinen tunnelma (ks. Brady \& Haapala 2003) sävyttää sekä saattoväen tunnemaailmaa että viimeisen säkeistön vastakkaisuuksien kautta jäsennettyä lupausta toivon päivästä.

Tämänpuoleisen surun ja tuonpuoleisen toivon ristiinlankeaminen saa kuvastonsa sateen ja paisteen limittymisestä: sinällään luonnossa useinkin tavattava samanaikaisuus mieltyy joko-tai-dikotomiaa rikkovan erikoisuutensa vuoksi ylimaallisena. Konkreettisella tasolla sateen läpi paistava aurinko vihjaa sateen hetkellisyyteen ja sitä seuraavaan paisteeseen, vertauskuvallisesti ehkä rajallisen elämän ja ikuisuuden teemoihin. "Alma"-runon lopussa konkretia on kuitenkin läsnä ainoastaan kuvaston taustalla, sillä sade ja päivänpaiste on runossa merkityksellistetty irti kirjaimellisesta tulkinnasta. Kyynelsade-yhdyssanan määriteosa kytkee pisarat kyyneleisiin, aiemmin kuvatun surun ilmentäjäksi, ja ilmauksessa "toivon päivä" genetiiviattribuutti lataa vuorokaudenajalle metaforisen tason. Hartauskirjallisuudestakin tuttu ilmaus viittaa toiveeseen ylösnousemuksesta. Monissa uskomusjärjestelmissä kuolema on nähty askeleena ylöspäin kosmologisessa ja henkisessä hierarkiassa, jolloin biologista tuhoutumista seuraa henkinen (jälleen)syntymä tai ylösnousemus. Tällaiseen maailmankuvallisen luottamuksen sanallistamiseen runo päättyy ja sulkee siten yksilön altruismia, yhteisöllistä muistamista ja kollektiivista uskoa limittävän sosiaalisen kehyksen.

Näin viimeisen säkeistön kyynelsadekuviossa ovat rinnakkain yksittäiseen tilanteeseen (Alman kuolema) sitoutunut suru sekä yleinen inhimillinen ja metafyysinenkin murhe. Näitä vasten piirtyy uskonvarma 
odotus, minkä vuoksi murhe sävyttyy ihanaksi ja toivon päivä nimetään armaaksi ja lempeäksi. Tämä luonnehdinta on rinnakkainen Alman luonnekuvauksen kanssa, mikä mahdollistaa ajatuksen, että Alman lähimmäisenrakkaus voidaan nähdä etiäisenä tai lupauksena taivaan oloista - silloin viidennessä säkeistössä mainitut turva, lohdutus ja armo syvenevät konkreettisesta auttamisesta kristillisiksi käsitteiksi. Samalla runo kasvaa yksittäisestä elämänkaaresta käsitykseen ihmisen osasta maailmassa, jolloin sekä kuolintapahtuma että kuoleman jälkeen oletettu olotila on mahdollista sävyttää lempeiksi.

\section{Lopuksi}

Runo "Alma" edustaa Kiven lyriikkaa kenties jopa prototyyppisesti.Tällä luonnehdinnalla tarkoitan, että runo asettaa näkyviin toistuvia aihelmia, käsittelytapoja ja esityskeinoja. "Almassa" ilmenevät esimerkiksi Kiven lyriikan romantiikkapiirteet ja elämäntarinaa kertovan runon konventionaaliset asetelmat, naiskuvan ihanteellisuus, viitteellisesti läsnä oleva hengellisyys sekä luontovertausten kautta välitetty kuvaus. Samat seikat ovat saaneet tutkijoiden huomiota muissa Kiven runoissa ehkä siksi, että aiemmat tulkitsijat ovat nähneet käsittelytavan näissä muissa runoissa jollakin tapaa onnistuneempana ja siksi "Alma" on ohitettu vain saman aiheen rinnakkaisilmiönä. Kuitenkin jos Kiven lyriikan aineksia verkotetaan runojen välillä, "Alma" asettuu kohtaan, josta on mahdollista osoittaa kytköksiä ja variaatioita usean runon suuntaan. Lempeän kuoleman aihelma on asetelmallinen osa monen runon tarinaa: se on dramaattinen ja koskettavuutta tuova elämänkaaren pääte, pohja ihmisen rajallisuuden pohdinnalle sekä runon henkilöiden tunnereaktioiden laukaisin. Koko Kiven lyriikassa voidaan erottaa esityksiä kuolemaan suuntautumisesta, kuolintapahtuman kuvauksia sekä kuolemaa seuraavien asioiden visiointia. Kaikille näille on yhteistä, että kuolema näyttäytyy lempeänä ja se esitetään vapauttavana ja estetisoituna. "Almassa" tämä asettelu on esitetty ehkä muita runoja keskitetymmin ja ilman voimakkaiden rinnakkaisteemojen läsnäoloa suhteellisen suoraviivaisen elämäntarinan ja sen eksplikoidun merkityksellistämisen kautta.

\section{LÄHTEET}

\section{Kaunokirjallisuus}

Kivi, Aleksis 2000: Runot. Helsinki: SKS.

\section{Muut lähteet}

Alanen, Yrjö 1947: "Puhtauden ihanne elämässä ja runoudessa". Teoksessa Eino Kauppinen, Viljo Kojo, Sulho Ranta, Jussi Snellman, Kaarlo Urpelainen, Matti Visanti ja Alpo Routasuo (toim.): Pilvilaiva. Aleksis Kivi ajan kuvastimessa. Helsinki: Otava, 66-77.

Brady, Emily and Arto Haapala 2003: "Melancholy as an Aesthetic Emotion" - Contemporary Aesthetics vol I (2003). <http://www.con- 
tempaesthetics.org/newvolume/pages/article.php?articlelD=2|4>. [14.10.2017.]

Demitshev, Andrei 1999: Kuolema työssä. Johdatus filosofiseen thanatologiaan (Diskursy smerti. Vvedenije $v$ filosofskuju tanatologiju). Suom. Jukka Mallinen. Jyväskylä:Atena Kustannus Oy.

Grünthal, Satu 1999: "Juhlarunoutta ja sekasointuja - lyriikka moniäänistyy". Teoksessa Yrjö Varpio ja Liisi Huhtala (toim.): Hurskaista lauluista ilostelevaan romaaniin. Suomen kirjallisuushistoria I. SKST 724:I. Helsinki: SKS, 3 I6-330.

Grünthal, Satu 2018: "Eksynyt impi, kristuksen morsian". Teoksessa Reetta Holopainen, Sakari Katajamäki ja Ossi Kokko (toim.): Ihmissydän. Henkilöitä ja kohtaloita A. Kiven maailmoissa. Helsinki: ntamo, $|8|-\mid 86$.

Haapala, Vesa 2016: "Yli luvallisen licentia poetican rajain. Huomioita Aleksis Kiven Kanervalasta kokoelmana”. Teoksessa Päivi Koivisto (toim.): Kanervakankaalla. Näkökulmia Aleksis Kiven runouteen. Joutsen/Svanen. Erikoisjulkaisuja I, II2-I4I. http://urn.fi/ URN:NBN:fi-fe20I70I26I334. [I5.7.2020]

Ilmakunnas, Johanna 2019: "Säätyläiset ja kuolemankulttuuri I600-luvulta 1800-luvulle".Teoksessa Ilona Pajari, Jussi Jalonen, Riikka Miettinen ja Kirsi Kanerva (toim.): Suomalaisen kuoleman historia. Helsinki: Gaudeamus, 126-154.

Kainulainen, Siru 2016:'”Mies' ja tunteet". Teoksessa Päivi Koivisto (toim.): Kanervakankaalla. Näkökulmia Aleksis Kiven runouteen. Joutsen/ Svanen. Erikoisjulkaisuja I, 29I-300. http://urn.fi/URN:NBN:fife20I 70I 26I346. [3 I.8.2020]

Kinnunen, Aarne 2002: Seitsemän veljestä ja lukemisen juonet. Helsinki: WSOY.

Kirkkopelto, Esa 200I: "Kivi, traaginen ja moderni. 'Tornin kello'-runo Hölderlinin tragediateorian valossa". Teoksessa Tuula Hökkä (toim.): Romanttinen moderni. Kirjoituksia runouskäsityksistä. SKS:n Toimituksia 830. Helsinki: SKS, 45-6I.

Koskenniemi,V.A. 1934: Aleksis Kivi. Helsinki:WSOY.

Koski, Kaarina ja Ulla Moilanen 2019: "Kuolema ja tuonpuoleinen". Teoksessa llona Pajari, Jussi Jalonen, Riikka Miettinen ja Kirsi Kanerva (toim.): Suomalaisen kuoleman historia. Helsinki: Gaudeamus, 6I-98.

Koskimies, Rafael 1974: Aleksis Kivi. Henkilö ja runous. Helsinki: Otava.

Kukkonen, Tiina 2015: "Uppoudun ja tukehdun: Häpeästä kuolemantoiveeseen ja itsemurhaan Aleksis Kiven teksteissä”. Thanatos vol. 4 I/20I5, 80-105.

Laitinen, Heikki 2016: "Aleksis Kiven säkeistömetriikka verrattuna Oksaseen ja Suonioon”. Teoksessa Päivi Koivisto (toim.): Kanervakankaalla. Näkökulmia Aleksis Kiven runouteen. Joutsen/ Svanen. Erikoisjulkaisuja I, 6I-9I. http://urn.fi/URN:NBN:fife20I70I26I332. [15.7.2020]

Lyytikäinen, Pirjo 2007: "Kangastus toivomme maasta. Aleksis Kivi romanttisen kaipuun tulkkina". Nostalgia. Kirjoituksia kaipuusta, ikä- 
västä ja muistista. Toim. Riikka Rossi ja Katja Seutu. Helsinki: SKS, 83-119.

Miettinen, Riikka 2019: "Itsemurha varhaismodernilta ajalta nykypäivään". Teoksessa llona Pajari, Jussi Jalonen, Riikka Miettinen ja Kirsi Kanerva (toim.): Suomalaisen kuoleman historia. Helsinki: Gaudeamus, 183-207.

Nummi, Jyrki 2005: 'Kuolla, nukkua vai uneksia? Aleksis Kiven 'lkävyys' ja runoilijan metamorfoosit”. Teoksessa Pirjo Lyytikäinen, Jyrki Nummi ja Päivi Koivisto (toim.): Lajit yli rajojen. Suomalaisen kirjallisuuden lajeja.Tietolipas 207. SKS: Helsinki, 66-103.

Nykysuomen sanakirja. Osa V. Päätoim. Matti Sadeniemi. Helsinki:WSOY.

Oja, Outi 2016: '"Äiti ja lapsi'. Tragedian nälänhädän aikaan" Teoksessa Päivi Koivisto (toim.): Kanervakankaalla. Näkökulmia Aleksis Kiven runouteen. Joutsen/Svanen. Erikoisjulkaisuja I, 245-255. http://urn. fi/URN:NBN:fi-fe20 I 70| 26 | 342. [3 I.8.2020]

Pettersson, Torsten 2016: "Onni ja yksinäisyys. Aleksis Kiven traaginen runomaailma". Teoksessa Päivi Koivisto (toim.): Kanervakankaalla. Näkökulmia Aleksis Kiven runouteen. Joutsen/Svanen. Erikoisjulkaisuja I, I0-27. http://urn.fi/URN:NBN:fi-fe20 I 70 I 26 I 329. [I5.7.2020]

Pitkäranta, Reijo 1999: "Kaarina Maununtyttären muistoruno". Teoksessa Yrjö Varpio ja Liisi Huhtala (toim.): Hurskaista lauluista ilostelevaan romaaniin. Suomen kirjallisuushistoria I. SKST 724:I. Helsinki: SKS, III.

Saarimaa, E. A. 195I: "Aleksis Kiven romantiikan piirteitä". Teoksessa Viljo Tarkiainen, Urpo Harva, Viljo Kojo, Unto Kupiainen, Sulho Ranta, Jussi Snellman, Kaarlo Urpelainen ja Matti Visanti (toim.): Kultanummi. Aleksis Kiven Seuran juhlajulkaisu. Helsinki: Otava, 47-56.

Sihvo, Hannes 2002: Elävä Kivi. Aleksis Kivi aikanansa. Suomalaisen Kirjallisuuden Seuran Toimituksia 889. Helsinki: SKS.

Sulkunen, Irma 2016: "Paimentytön liikutus. Hurmosherätykset, sekularisaatio ja maailmankuvan muutos". Teoksessa Irma Sulkunen, Marjaana Niemi ja Sari Katajala-Peltomaa (toim.): Usko, tiede ja historiankirjoitus. Suomalaista maailmankuvaa keskiajalta 1900-luvulle. Historiallisia tutkimuksia 27I. Helsinki: SKS, I00-130.

Viljanen, Lauri 1954: "Aleksis Kiven runomaailma". Teoksessa Lauri Viljanen (toi.) Aleksis Kivi. Kootut runot. Helsinki:WSOY, I-I83.

Viljanen, Lauri 1964: "Aleksis Kivi”. Teoksessa Lauri Viljanen (toim.): Suomen kirjallisuus III. Turun romantikoista Aleksis Kiveen. Helsinki: SKS ja Otava, 462-580.

\section{Kirjoittaja}

Mikko Turunen, FT, lehtori

mikko.j.turunen@gmail.com 